\title{
Does the Auditor Have a Direct Influence on the Financial Statement Quality?
}

\author{
Tatiana Dolgikh
}

\begin{abstract}
:
In the modern process of globalization, IFRS standards are widely used in the financial world, Russian Federation is one of these examples. The application of IFRS in Russian Federation first began in the early 90-ies of the twentieth century. During IFRS adoption many companies were involved in this process. Nowadays, a big part of all Russian companies obligatory use IFRS standards to prepare their statements. The purpose of this article is to analyse current practices of financial reporting procedures, its compliance with the rules of the IAS 1 as well as identifying the dependencies between the auditor selection and the quality of reporting. For this paper, a special Questionnaire was developed and for each selected organization a special profile, which included analysis of all financial statements for the period of the 2015 year was created. The study shows that the financial reports quality of the largest Russian companies on a high level. However, many companies face the problem of RAS and IFRS differences during reports transformation that directly influences its quality. During the study process it becomes clear, that auditor has a direct impact on the financial statements quality.
\end{abstract}

Key words: Reports; Quality; IFRS; Russian Companies.

JEL classification: M41, M42.

\section{Introduction}

The application of International Financial Reporting Standards (IFRS) aims at achieving transparency of the company's activity, as well as it creates the opportunity to make reasonable managerial decisions, estimate the financial condition and implement forecasts. Due to the active process of globalization in world economic systems, IFRS standards are widely used in the modern financial world. The need for the development of IFRS as a single set of the rules for accounting and reporting systems was primarily caused by the establishment of uniform rules on the international financial market. The concept of IFRS as the global standards has been publicly supported by many international authoritative organizations, including: the group "Big twenty" (G20), the World Bank, the International Monetary Fund (IMF), the Basel Committee, the International

\footnotetext{
Tatiana Dolgikh; University of Economics, Prague, Faculty of Finance and Accounting, Department Accounting and Corporate Financial Management, W. Churchill Sq. 4, 13067 Prague, Czech Republic, <tatiana.dolgikh@vse.cz>.

This paper has been prepared within the research project Economic Impacts of the IFRS Adoption in Selected Transition Countries supported by the Czech Science Foundation, No. 15-01280S.
} 
Organization of Securities Commissions (IOSCO) and the International Federation of Accountants (IFAC).

The application of IFRS in Russian Federation first began in the early 90-ies of the twentieth century. One of the first Russian companies that have prepared financial statements in accordance with IFRS were JSC "Avtovaz" (1994) and JSC "Gazprom" (1996). Financial statements in accordance with IFRS were demanded from companies in the oil and energy sector because of their listing on the London stock exchange. The first obligatory using of IFRS started from the letter of Central Bank of the Russian Federation (No. 181-T from 25.12.2003) by which all companies in the banking sector had to prepare financial statements in accordance with IFRS starting from January 2004. Open joint stock companies whose shares were traded on the securities markets started to prepare quarterly and annual financial statements in accordance with IFRS or US GAAP from January 2005 (order No. 05-5/PZ-n from 16.03.2005 of the Federal Service for Financial Markets of Russia). Since January 2007 the companies issuing debt instruments also began to prepare financial statements in accordance with IFRS or US GAAP. The legal basis for the adoption of IFRS on the territory of the Russian Federation is the Federal Law No. 208-FZ from 27.07.2010 "On consolidated financial reporting". Russian Federation chose the way of IFRS adoption to national standards. Currently, some national standards have direct references to IFRS. Formal recognition of IFRS standards and their Clarifications was received at the end of 2011 (the order of the Ministry of Finance No. 160n from 25.11.2011). Thus in 2011 Russian Federation recognized the first 63 IFRS standards and interpretations for them.

Including the latest updates Jurisdictional Profile of Russian Federation according to IFRS Foundation presents next: in addition to listed companies, the following companies are required to use IFRS Standards for consolidated financial statements:

- banks,

- insurance companies,

- non-state pension funds,

- management companies of investment funds, investment unit trusts and nonstate pension funds,

- clearing organizations,

- federal state-owned enterprises as well as joint-stock companies, whose shareholder is the Russian Federation (per the Russian Government decision),

- any other company that prepares consolidated financial statements due to requirements of other laws or its charter documents. 
Besides, all non-listed companies that control subsidiaries, consolidated financial statements into a prospectus are required to include the IFRS (IFRS Foundation, 2016).

So, Russian Federation had a quite long journey of IFRS adoption. This fact allows to conduct a study regarding the quality of prepared financial statements and make the conclusion about the success of adaptation procedures and the informatively content of Russian financial statements.

The relevance of the research topic can be explained by the globalization process. Despite the current sanctions, European Union is still one of the most important trade partners of Russian Federation (45.7\% - according to the Federal customs service of Russia, 2016). For both sides of commercial relationships is very important to know the actual and relevant information about the partner's financial condition. Thus, this article presents a review of the financial reports quality of the largest Russian companies for the year 2015 prepared in accordance with IFRS. The purpose of this article is to analyse current practices of financial reporting procedures, its compliance with the rules of the IAS 1 as well as identifying the dependencies between the auditor selection and the quality of reporting.

The article is divided into five sections. The introduction outlines the paper's goal, literature review describes basic literature. Methodology section provides data for research, next section provides discussion and results, the final section concludes.

\section{Literature Review}

Since 2013 Deloitte started to publish an Annual review of the practical application of IFRS by Russian companies. The impact of IFRS adoption on the preparation of financial statements was examined by accounting researchers as well. (Chaya, 2015) argues that IFRS implementation becomes an advantageous mechanism not only for the enterprises themselves but also for potential investors, which positively affects the state of the entire financial market. In addition, the preparation of financial statements according to IFRS takes into account the specifics of activity of the enterprise and improves the quality of the reporting. (Getman, 2014) analyses the system of IFRS: its principles, formation, advantages, and feasibility of implementation. Special attention is paid to the selection of the auditing company. (Vahrushina, 2014) deals with the theoretical and methodological problems of preparation financial statements in accordance with IFRS, including the techniques that allow transforming the Russian accounting statements to the IFRS format.

As it was noted by Alon $(2013,2014)$, the process of harmonization with the IFRS in Russia is very specific because of some reasons. Russia is an example of a 
country facing to so-called dual institutionalism. It means that IFRS didn't replace RAS, but companies use RAS and IFRS simultaneously, even in the case of mandatory use of IFRS standards. This leads to the use of two different logics of the accounting process. Thus, Russian companies are insufficiently motivated to apply the IFRS, and sometimes do not understand the usefulness of international practices and views (Dolgikh, 2017). On the other hand, there is an empirical evidence that Russia leading firms cross-listed on the London Stock Exchange provide users with more value-relevant information. This might result in improved accounting quality once the adoption process is finished (Kim, 2013). Some of the researchers find that there is no evidence of increased value relevance of financial reporting to external users of financial information after adopting IFRS when comparing and evaluating the two regimes (RAS and IFRS) unconditionally (Garanina and Kormiltseva, 2014).

Big attention in the literature is paid to the independence of the auditor. As an example, (Sucher and Bychkova, 2010) find out that companies with foreign investments are more likely to establish a comparatively desirable audit system than other firms. From another perspective, they concluded that the less independent and professional audit system of Russian firms than the international practice is deeply rooted in a weak countervailing power of outsider board directors against management executives, low foreign direct investment within the country, and a loose management discipline of independent companies that are operating in isolation in terms of their capital relationship. The same conclusion can be found in a study of (Iwasaki, 2013).

Thus, the following hypothesis was formulated during the study:

$\mathrm{H}$ : Auditor has the direct influence on the financial statements quality.

\section{Data and Methodology}

\subsection{Companies selection methodology for the research}

Empirical data were collected from the website of RBC (Ros Business Consulting). This company exists for over 20 years and it is the largest Russian business media holding company, which is represented on the Internet, television, and press. Every year RBC makes the list of 500 largest Russian companies. Companies which formed their statements on the managerial basis have been removed from this list. Among these 474 just 193 companies prepare their financial statements in accordance with IFRS, 266 prepare their statements in accordance with Russian Accounting Standards (RAS) and remaining 15 firms publish their statements in accordance with US GAAP. (Fig. 1). 


\section{Fig. 1 Standards applied for financial reporting}

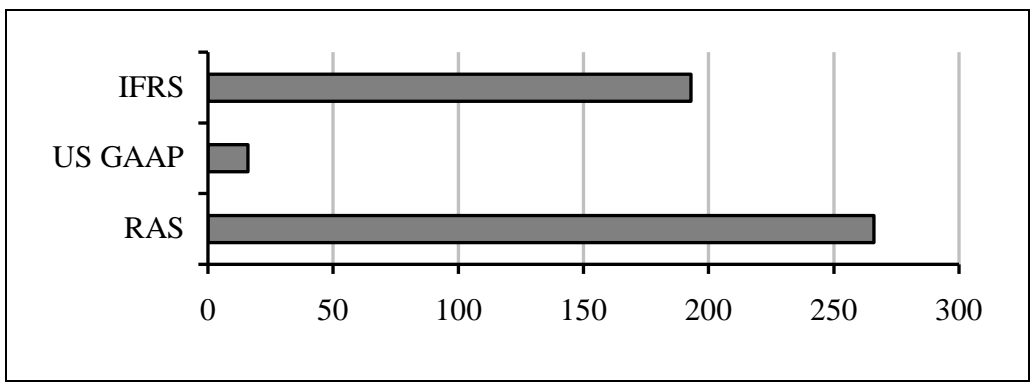

Source: Authorial computation based on RBC list of 500 largest Russian companies.

82 out of 474 companies are Public sector companies, 375 of the companies are from Private sector and 17 submit to the Joint enterprise (Fig. 2).

\section{Fig. 2 Company status}

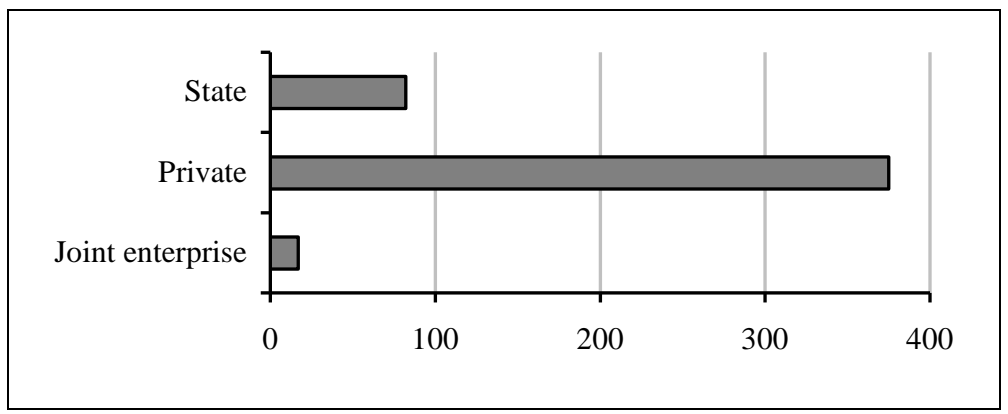

Source: Authorial computation based on RBC list of 500 largest Russian companies.

By dividing the companies into different sectors of the economy, we can notice that most of the companies belong to the manufacturing industry - 126 firms (43\%). The largest percentage of companies that use IFRS is observed in the financial sector - 92\%, which follows from the mandatory application of IFRS by banks and insurance organizations (as described in the introduction). A second and third place for the largest percentage of reporting in accordance with IFRS is mining industry and IT $-58 \%$ and $50 \%$ respectively. The lowest percentage has the construction and trade $-19 \%$ and $21 \%$ respectively (Fig. 3 ). 
Fig. 3 Percentage and sector of the economy which uses IFRS for the preparation of the financial statements (in \%)

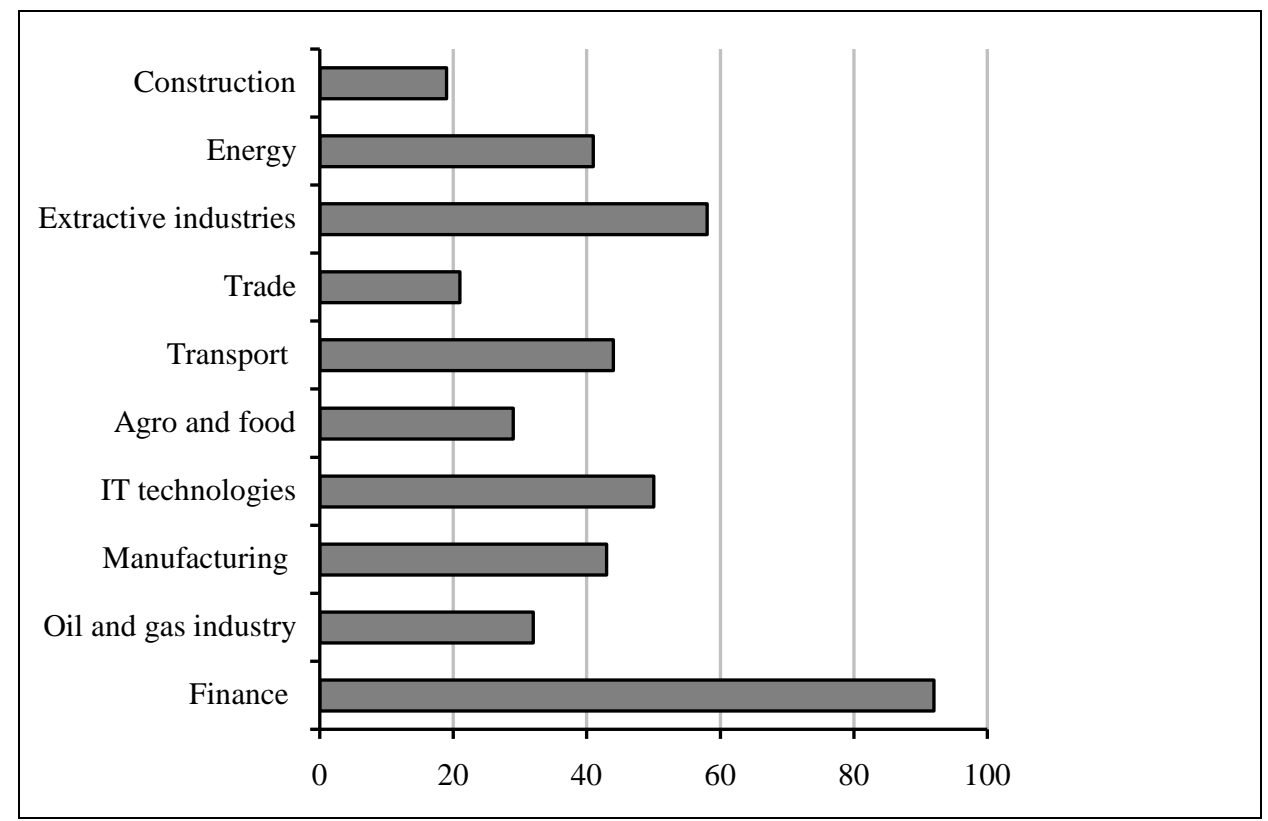

Source: Authorial computation based on RBC list of 500 largest Russian companies.

As the study examines the effects of IFRS adoption, only IFRS adopters are included in the sample, but without firms operating in the financial sector. Sample companies are divided into following economy sectors (Oil and gas industry, Manufacturing, IT Technologies, Agro and food, Transport, Trade, Extractive industries, Energy, Construction). And finally, there were selected first two companies from rating list of each economic sector in the study. For Agro and food sector only one company was selected, because of unavailability of other companies' financial statements. From manufacturing industry first five companies sector were selected because of the big size of this sector (Fig. 4). 
Fig. 4 Companies selection methodology for the study

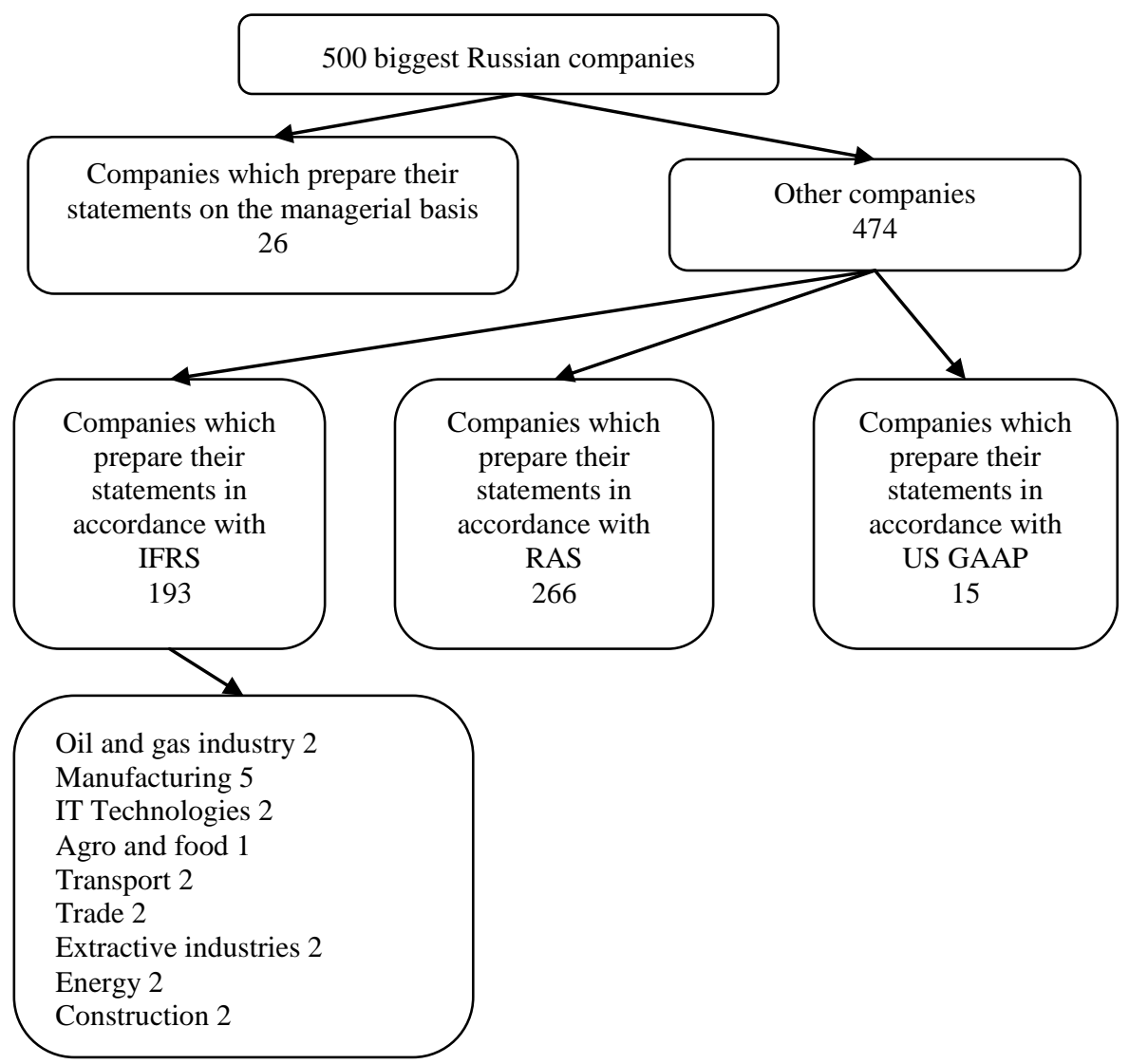

Source: Authorial computation based on RBC list of 500 largest Russian companies.

Selection of the companies for this study can be explained by the fact that all these companies are the largest representatives of every sector of the economy, and also they could be potential partners not only for domestic but also for international cooperation. Thus, annual reporting of these companies should be informative, qualitative, and assume all information about their activities. The study was conducted on the basis of the financial statements of these companies (Table 1). 
Tab. 1 List of analyzed companies

\begin{tabular}{|c|c|c|c|c|c|c|c|c|c|}
\hline No. & $\begin{array}{l}\text { Company } \\
\text { name }\end{array}$ & Status & $\begin{array}{l}\text { Main } \\
\text { office }\end{array}$ & Specialization & $\begin{array}{l}\text { Rev. } \\
\text { (bil.rub) } \\
2015\end{array}$ & $\begin{array}{l}\text { Rev.'s } \\
\text { dynamic } \\
(\%)\end{array}$ & $\begin{array}{l}\mathrm{P} / \mathrm{L} \\
\text { (bil.rub) } \\
2015\end{array}$ & $\begin{array}{l}\text { P/L } \\
\text { dynamic } \\
(\%)\end{array}$ & $\begin{array}{l}\begin{array}{l}\text { No. of } \\
\text { employees }\end{array} \\
\text { (ths. } \\
\text { people) } \\
\end{array}$ \\
\hline 1 & $\begin{array}{l}\text { Company PJSC } \\
\text { Gazprom }\end{array}$ & State & Moscow & Oil and gas & 5985 & 9 & 805 & 412 & 450 \\
\hline 2 & PJSC LUKOIL & Private & Moscow & Oil and gas & 5174 & 10 & 293 & -26 & 110 \\
\hline 5 & $\begin{array}{l}\text { Russian } \\
\text { railways }\end{array}$ & State & Moscow & Railway transport & 1991 & 11 & 8,182 & - & 1085 \\
\hline 8 & PJSC Magnit & Private & Krasnodar & Retail sale & 951 & 25 & 59 & 24 & 255 \\
\hline 10 & $\begin{array}{l}\text { X5 Retail } \\
\text { Group }\end{array}$ & Private & Moscow & Retail Sale & 809 & 28 & 14 & 12 & 117 \\
\hline 11 & $\begin{array}{l}\text { JSC INTER } \\
\text { RAO }\end{array}$ & State & Moscow & Electroenergetics & 805 & 9 & 24 & 145 & 58 \\
\hline 13 & PJSC Rosseti & State & Moscow & Electroenergetics & 767 & 1 & 82 & - & 218 \\
\hline 17 & EVRAZ & Private & Moscow & Black metallurgy & 534 & 6 & -44 & - & 94 \\
\hline 18 & UC Rusal & Private & Moscow & Colour metallurgy & 529 & 47 & 34 & - & 61 \\
\hline 20 & Norilsk Nickel & Private & Moscow & Colour metallurgy & 501 & 12 & 104 & 11 & 82 \\
\hline 24 & $\begin{array}{l}\text { Aeroflot - } \\
\text { Russian airlines }\end{array}$ & State & Moscow & Aviation transport & 415 & 30 & $-6,494$ & - & 32 \\
\hline 25 & PAO Severstal & Private & Moscow & Ferrous metallurgy & 387 & 22 & 34 & - & 52 \\
\hline 27 & $\begin{array}{l}\text { PAO Sibur } \\
\text { holding }\end{array}$ & Private & Moscow & $\begin{array}{l}\text { Chemicals and } \\
\text { petrochemicals }\end{array}$ & 380 & 5 & 6,505 & -74 & 26 \\
\hline 34 & PJSC MegaFon & Private & Moscow & Telecommunications & 313 & 0 & 39 & 6 & 31 \\
\hline 37 & $\begin{array}{l}\text { PJSC } \\
\text { Rostelecom }\end{array}$ & State & Moscow & Telecommunications & 297 & -1 & 14 & 9 & - \\
\hline 39 & $\begin{array}{l}\text { PJSC United } \\
\text { Aircraft } \\
\text { Corporation }\end{array}$ & State & Moscow & Aircraft building & 279 & 18 & 5,373 & 101 & 99 \\
\hline 46 & SUEK Group & Private & Moscow & Coal mining & 252 & 30 & 12 & - & 31 \\
\hline 49 & PJSC Alrosa & State & Moscow & Diamond mining & 225 & 8 & 32 & - & 30 \\
\hline 74 & $\begin{array}{l}\text { PJSC } \\
\text { MOSTOTREST }\end{array}$ & $\Gamma$ State & Moscow & $\begin{array}{l}\text { Infrastructure } \\
\text { construction }\end{array}$ & 143 & -5 & 4,232 & -30 & 29 \\
\hline 143 & $\begin{array}{l}\text { ROS AGRO } \\
\text { PLC }\end{array}$ & Private & Moscow & Agro and food & 72 & 23 & 24 & 17 & 9 \\
\hline
\end{tabular}

Source: (RBK statistics, 2016).

As the Table shows there are 20 companies from different sectors of the economy, 95\% of them have a Head office in Moscow. 55\% of these companies have private status and $45 \%$ of them are state companies. Except for two, all companies have a positive revenue's dynamic in 2015 . Sixteen of these companies $(80 \%)$ have profit 
at the end of the reporting period and nine of them (56\%) have positive profit dynamic. The largest number of employees have Russian railways (1 085000 people) and the smallest number of employees have the company from Agro and food area - Ros Agro PLC (only 9000 people).

\subsection{Financial statement analysis of the selected companies}

A special questionnaire that includes 20 questions (Appendix 1) was developed to assess the selected aspects of reporting quality. A special profile assessing financial statements for the 2015-period (Table 2), was constructed for each firm. All processed data were entered into a table, where each answer was assigned the highest rating of 5 (fully meets) and the lowest rating of 0 (completely inappropriate). Additionally, each assessment was assigned a weight indicator in the General scale (in accordance with the importance of the applicable requirements). The company whose statements are most consistent with the requirements of the IAS 1 was chosen by the total score. The questionnaire also includes additional questions to better understanding the quality of the prepared statements.

\section{Tab. 2 Profile of the company PJSC Alrosa}

\begin{tabular}{|c|c|c|c|c|}
\hline $\mathbf{N}$ & PJSC ALROSA & Mark & $\begin{array}{l}\text { Weight } \\
(\%)\end{array}$ & $\begin{array}{l}\text { Final } \\
\text { result }\end{array}$ \\
\hline 1 & Yes - company has full set of financial statements & 5 & 12 & 0,6 \\
\hline 2 & $\begin{array}{l}\text { Yes - financial statements of the company match the } \\
\text { structure in accordance with IAS } 1\end{array}$ & 5 & 8 & 0,4 \\
\hline 3 & $\begin{array}{l}\text { Yes - The Statement of Financial Position includes } \\
\text { minimum line items }\end{array}$ & 5 & 9 & 0,45 \\
\hline 4 & $\begin{array}{l}\text { Yes - discloses additional lines in The Statement of } \\
\text { Financial Position (Disaggregated some line items listed in } \\
\text { paragraph 5) }\end{array}$ & 2 & 7 & 0,14 \\
\hline 5 & $\begin{array}{l}85 \% \text { entity does not disclose the full information about } \\
\text { each class of share capital in the financial statements (not } \\
\text { specified shares held by the entity or by its subsidiaries or } \\
\text { associates) }\end{array}$ & 4 & 8 & 0,32 \\
\hline 6 & $\begin{array}{l}\text { Yes - Profit and Loss Statement and Other Comprehensive } \\
\text { Income includes minimum line items in accordance with } \\
\text { the paragraph } 82 \text { of IAS } 1\end{array}$ & 5 & 9 & 0,45 \\
\hline 7 & $\begin{array}{l}\text { No - the entity does not disclose the amount of income tax } \\
\text { relating to each item of other comprehensive income }\end{array}$ & 0 & 7 & 0 \\
\hline 8 & $\begin{array}{l}\text { Yes - the entity makes Statement of Changes in Equity in } \\
\text { accordance with IAS } 1\end{array}$ & 5 & 9 & 0,45 \\
\hline
\end{tabular}




\begin{tabular}{|c|c|c|c|c|}
\hline $\mathbf{N}$ & PJSC ALROSA & Mark & $\begin{array}{l}\text { Weight } \\
(\%)\end{array}$ & $\begin{array}{l}\text { Final } \\
\text { result }\end{array}$ \\
\hline 9 & $\begin{array}{l}\text { Yes - the entity discloses the amount of paid dividends to } \\
\text { shareholders during the period }\end{array}$ & 5 & 7 & 0,35 \\
\hline 10 & $\begin{array}{l}80 \% \text { - The Cash Flow Statement does not include } \\
\text { minimum line items in accordance with IAS (there are } \\
\text { were not classified cash flows from operating activities) }\end{array}$ & 4 & 9 & 0,36 \\
\hline 11 & $\begin{array}{l}\text { Yes - the entity discloses the significant amount of cash } \\
\text { and cash equivalents that are not available for use by the } \\
\text { group }\end{array}$ & 5 & 6 & 0,3 \\
\hline \multirow[t]{2}{*}{12} & $\begin{array}{l}\text { Yes - the entity creates Provisions for Post-employment } \\
\text { benefit obligation, Currency translation differences, and } \\
\text { Change in fair value of available for sale investments. } \\
\text { Also, company makes some Accruals on Provision for land } \\
\text { recultivation, Accrual for employee flights and holidays } \\
\text { and other accruals on taxes and different expenses which } \\
\text { are not directly mentioned in Notes) }\end{array}$ & 5 & 9 & 0,45 \\
\hline & Total score & $\mathrm{x}$ & 100 & 4,27 \\
\hline
\end{tabular}

\section{Additional questions}

1 The entity uses mixed method of short-term/long-term assets and liabilities classifications in a Statement of Financial Position

2 The entity discloses revenues and expense for the period in one statement

3 The entity classifies expenses in The Profit and Loss Statement and Other Comprehensive Income for the period by function

$4 \quad$ The entity uses direct method of reporting cash flows from operating activities

The entity discloses such critical accounting estimates and judgments in applying

5 accounting policies like Impairment provision for receivables, Impairment of property, plant, and equipment, Estimated impairment of goodwill, Tax legislation, Useful lives of property, plant, and equipment, Pension benefits, Asset retirement obligations

6 PWC company verifies the financial statements of the entity

$7 \quad$ Yes - the entity discloses both indexes of EPS (earnings per share) in The Profit and Loss Statement

8 The entity uses new titles for its statements

951 pages contains Notes section

Source: Authorial computation. 


\section{Results and Discussion}

Such profiles were created for each of 20 companies. In general, the analysis of the financial reports quality allows to make following conclusions:

- Structure of all financial statements has a good quality, but some of the companies do not divide long-term debt on long-term debt and current portion of long-term debt and do not classify cash flows from operating activities;

- All statements include minimum line items in accordance with the IAS 1 and $85 \%$ of all companies also including additional line items in their reports;

- Information about share capital has the different level of disclosure. Some companies describe in detail establishment procedure of the company, types of issued shares and the rights of each of them also paid great attention to dividend policy. However, a few companies do not specify shares held by the entity or by its subsidiaries or associates;

- Only a few companies disclose the amount of income tax relating to each item of other comprehensive income (40\%), mainly this information included in Notes section;

- All the companies inform in Notes section the amount of paid dividends to shareholders during the period and $10 \%$ of them resolved not to pay dividends for 2014;

- Only $25 \%$ of the companies disclose the significant amount of cash and cash equivalents that are not available for use by the group;

- Not all the companies have some estimation of uncertainty at the end of the reporting period. Notes section rarely describes or specifies kinds of created reserves or accruals. Mostly, the companies create some reserves connected with different types of payments to employees, and only a few companies estimate the risk of goods return, legal proceedings, or bad debts. Many of the companies include such item as other accruals in their statements, but the reasons for creation this type of accruals are not clear and no calculation cannot be found.

The final result of the study shows that the best quality of statements has Company Gazprom with total score 4.61, Lukoil Company and Aeroflot-Russian airlines with total score 4.54 and 4.47 respectively (Fig. 5). 
Fig. 5 Total score of the financial statements quality

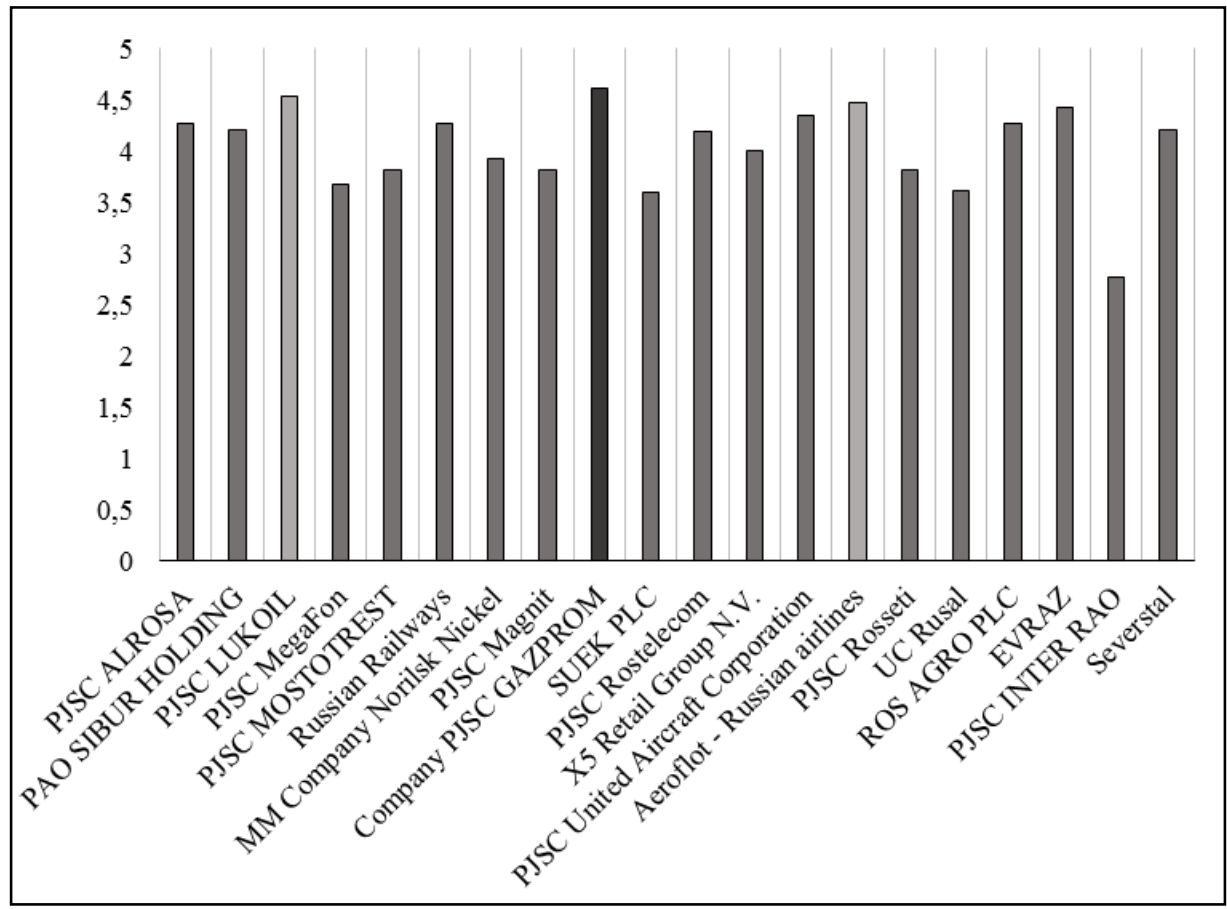

Source: Authorial computation.

The study also included additional questions that had no influence on the final assessment, however, they highlighted the specificity of disclosing information in the financial statements. $80 \%$ of the companies use mixed method of disclose short-term/long-term assets and liabilities in a statement of financial position. The companies more frequently disclose revenues and expenses for the period in one statement $(60 \%)$ than in two separate statements. Classifying of expenses in the statement of profit or loss and other comprehensive income for the period by function or by nature divided the following way - 65\% and 35\% respectively. The more popular method of reporting cash flows from operating activities is indirect, $85 \%$ of the companies use this method. The study shows that the companies use oftener services of KPMG auditor company (35\%), EY (Ernst \& Young Global Limited) and $\mathrm{PwC}$ (PricewaterhouseCoopers) took the second place and have the same percent $-25 \%$. It is interesting to note that $15 \%$ of all companies use the services of Russian auditor companies. As an example, the auditor of Company Gazprom is Limited Liability Company Accountants and business advisors (FBK, LLC) that do not belong to the so-called Big four. All companies except one disclose both indexes of EPS (earnings per share) in the Statement of profit or loss and other comprehensive income for the period in accordance with IAS 33. 32\% 
of all studied companies has a medium size Notes section - from 51 to 80 pages, $26 \%$ of companies have a long part of this statement and the rest part has not so big part of Notes - less than 50 pages.

Based on the study, the disclosure of the sources of uncertainty is the most challenging issue for many companies during the preparation of financial statements. Russian accountants wary of these estimated items (such as provisions and assets impairment) because they represent an approximate value, which is determined on the basis of calculations and professional judgment. The Russian Accounting Standards (RAS) mention the following types of provisions: doubtful debts, impairment of financial investments, impairment of inventories, warranty service and warranty repairs, vacation payments, remuneration payments based on the year's results, obligations for termination of business activities. RAS and IFRS put a different meaning to the same terms. As it can be seen from the previous list, provisions under RAS include not only provisions (as liabilities), but also impairment of assets. This problem was clearly visible in the study and it might endanger the expected improvement in accounting quality following the IFRS adoption.

Summarized study's results show that different auditing companies have the different total score of financial reports quality and different variation of this indicator (Fig. 6).

Fig. 6 Total score of each company depending on selected auditing company

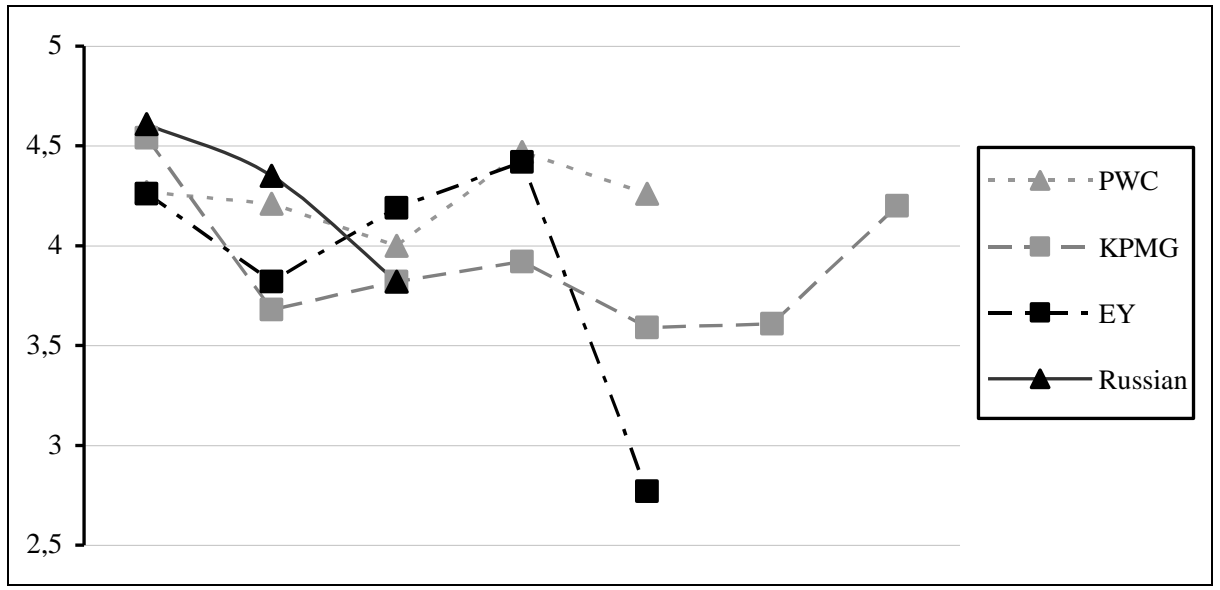

Source: Authorial computation.

As it shown in the figure 6, we cannot estimate the homogeneity of data and their deviation from the mean value, which would help to confirm or reject the hypothesis. Therefore, based on available outcome data following indicators for the analysis were calculated (table 3 ). 
Dolgikh, T: Does the Auditor Have Direct Influence on the Financial Statement Quality?

Tab. 3 Variability indexes of individual auditing firms

\begin{tabular}{lllll}
\hline Indicator & PWC & KPMG & EY & $\begin{array}{l}\text { Russian } \\
\text { Auditing } \\
\text { Companies }\end{array}$ \\
\hline Standard deviation & 0,1678 & 0,3499 & 0,6647 & 0,4026 \\
Variance & 0,0282 & 0,1224 & 0,4418 & 0,1621 \\
Mean (average) & 4,24 & 3,91 & 3,89 & 4,26 \\
Coefficient of variation $(\%)$ & 4 & 9 & 17 & 9 \\
\hline
\end{tabular}

Source: Authorial computation.

The most important indicators are Standard deviation and Coefficient of variation. Standard deviation is a measure that is used to quantify the amount of variation or dispersion of a set of data values. The coefficient of variation shows the measure of data variation in percent. As we can see Standard deviation for all of these auditing companies is not so high. Thus, the reporting quality of an individual company within a single auditor is not much different from the mean (average). The coefficient of variation also shows that the deviation from the mean value on the low percentage level and fluctuates from $4 \%$ to $17 \%$.

In addition, one more criteria was tested in the study - Kruskal-Wallis test, which tool is used to compare two or more independent samples of equal or different sample sizes. The hypothesis that will be tested by using the Kruskal-Wallis test, is that each auditing company has similar quality of audited financial statements (i.e. the observed differences in group median values of the total score of each company is not essential). For this test was used statistic program SPSS Statistics. Regarding calculations, Kruskal-Wallis chi-square is 4.21 with $3 \mathrm{df}$, the significance level is $\alpha=0.05$, $p$-value $=0.240$. (The critical chi-square values for $\mathrm{df}=3, \mathrm{p}=0.05$ is 7.82 ). Using the $\mathrm{P}$-value approach: The $\mathrm{p}$-value is $\mathrm{p}=0.240$, and since $\mathrm{p} \geq 0.05$, it is concluded that the hypothesis is not rejected. Therefore, there is not enough evidence to claim that some of the total scores of each company medians are unequal, at the alpha $=0.05$ significance level.

\section{Conclusion}

The study shows that the financial reports quality of the largest Russian companies for 2015 are prepared in accordance with IFRS on a high level. However, many companies face the problem of RAS and IFRS differences during reports transformation that directly influences their quality. The different content of the term "provisions" under RAS and IFRS can be mentioned as a typical example, when entities struggle to reconcile RAS figures to IFRS figures. That's why Notes section rarely describes or specifies kinds of created provisions or accruals. Mostly, companies create some provisions connected with different types of 
payments to employees, and only a few companies estimate the risk of goods return, legal proceedings, or bad debts. Many companies have in their statements such item like other accruals, but the reasons for creation this type of accruals are not clear and no calculation cannot be found.

Best reporting quality has Gazprom company, which has a long-term practice of reporting in accordance with IFRS (from 1996, Gazprom was one of the first Russian companies that have prepared financial statements in accordance with IFRS). The same result can be seen in Oil and gas industry because of rich experience in the international market. Also, during the study process it became clear, that the auditor has a direct impact on the financial statements quality. On the other hand, the study does not provide a complete view on reporting and disclosure quality, as it focuses only on the fulfillment of IAS 1 requirements. An alternative research setting might thus lead to the different findings. The inspection of more complex disclosure scores is our suggestion to the future research.

\section{References}

Alon, A., 2013. Complexity and Dual Institutionality: The case of IFRS adoption in Russia. Corporate Governance: An international Review 1, 42-57. DOI: 10.1111/j.1467-8683.2012.00927.x.

Alon, A., Dwyer, P., 2014. Early adoption of IFRS as a strategic response to transitional and local influences. The international journal of accounting 3, 348370. DOI: 10.1016/j.intacc.2014.07.003.

Chaya, V. T., 2015. Fundamentals of reporting transformation of small and medium-sized enterprises in accordance with IFRS. 5 October 2015. Audit No. 10-2015. Available from: <http://gaap.ru/articles/Osnovy_ transformatsii_otchetnosti_malykh_i_srednikh_predpriyatiy_v_sootvetstvii_s_MS $\mathrm{FO} />$. [5 October 2015].

Dolgikh, T., 2017. The IFRS Adoption by BRICS Countries: A Comparative Analysis. Springer Proceedings in Business and Economics, 373-383. DOI 10.1007/978-3-319-49559-0_35.

Federal Law No. 208-FZ from 27.07.2010 On consolidated financial reporting, 2010. Available from: <http://www.consultant.ru/document/cons_doc_LAW_ 103021/>. [27 July 2010].

Getman, V. G., 2014. International Financial Reporting Standards. INFRA-M, Moscow.

Garanina, T. A., Kormiltseva, P. S., 2014. The effect of international financial reporting standards (IFRS) adoption on the value relevance of financial reporting: 
a case of Russia. Research in Emerging Economies, 27-60. DOI: 10.1108/s14793563(2013)0000013007.

IAS 1 Presentation of Financial Statements, version as of 18 February 2011. Available from: <http://ec.europa.eu/internal_market/accounting/docs/consolida ted/ias1_en.pdf>. [18 February 2011].

IFRS application around the world. Jurisdictional profile: Russia, 2016. IFRS org. Available from: <http://www.ifrs.org/Use-around-the-world/Documents/ Jurisdiction-profiles/Russia-IFRS-Profile.pdf>. [16 June 2016].

Iwasaki, I., 2013. What Determines Audit Independence and Expertise in Russia? Firm-Level Evidence, 2014. Corporate Ownership and Control 2. DOI: 10.22495/cocv11i2p7.

Kim, O., 2013. Russian Accounting System: Value Relevance of Reported Information and the IFRS Adoption Perspective. The International Journal of Accounting 4. 525-547. DOI: 10.1016/j.intacc.2013.10.007.

Letter of Central Bank of the Russian Federation No. 181-T from 25.12.2003, 2003. Available from: <http://www.consultant.ru/document/cons_doc_LAW_ 45923/>. [25 December 2003].

Order No. 05-5/PZ-n of the Federal Service for Financial Markets of Russia from 16.03.2005, 2005. Available from: <http://www.consultant.ru/document/ cons_doc_LAW_53281/>. [16 March 2005].

Order of the Ministry of Finance No. 160n from 25.11.2011, 2011. Available from: <http://www.consultant.ru/document/cons_doc_LAW_124550/>. [25 November 2011].

Scher, P., Bychkova, S., 2010. Auditor independence in economies in transition: a study of Russia. European accounting review 4, 817-841. DOI: 10.1080/09638180120069142.

The rating of the largest companies in Russia, 2015. RBK magazine, Moscow. Available from: <http://www.rbc.ru/rbc500/>. [22 September 2016].

Vahrushina, M. A., 2014. International Financial Reporting Standards. National education, Moscow. 


\section{Appendix 1: Questionnaire}

\section{Yes/No}

1. Does the entity have the whole set of financial statements?

2. Do the financial statements match the structure in accordance with IAS 1?

3. Does the Statement of Financial Position include minimum line items in accordance with paragraph 54 of IAS 1 ?

4. Does the entity disclose additional lines in the Statement of Financial position, which are important for understanding its financial situation?

5. Does the entity disclose information about each class of share capital in the financial statements in accordance with the paragraph 79 of IAS 1? (and in which statement - Statement of Financial Position, Statement of Change in Equity or in Notes)

6. Does the Profit and Loss Statement and Other Comprehensive Income include minimum line items in accordance with paragraph 82 of IAS 1 ?

7. Does the entity disclose the amount of income tax relating to each item of other comprehensive income, including reclassification adjustments in accordance with paragraph 90 of IAS 1? (in which statement - statement of profit or loss and other comprehensive income or in notes)

8. Does the entity make Statement of Changes in Equity in accordance with paragraph 106 IAS 1 ?

9. Does the entity disclose the amount of paid dividends to shareholders during the period?

10.Does the Cash Flow Statement include minimum line items in accordance with IAS 7?

11.Does the entity disclose a significant amount of cash and cash equivalents that are not available for use by the group? (restricted cash)

12.Does the entity disclose information of estimation uncertainty at the end of the reporting period, which has a significant risk of resulting in a material adjustment to the carrying amounts of assets and liabilities within the next financial year in accordance with paragraph 125 of IAS 1 ?

\section{Additional questions}

1. Does the entity disclose short-term/long-term assets and liabilities in a Statement of Financial Position as separate classifications or disclose items sorted in accordance with the liquidity, or use a mixed method?

2. Does the entity disclose revenues and expense for the period in one statement or in two separate statements? 
3. Does the entity classify expenses in the Profit and Loss Statement and Other Comprehensive Income by function or by nature?

4. Which method of reporting cash flows from operating activities does the entity use? (direct or indirect)

5. Which significant accounting policies does the entity disclose in its Notes in accordance with paragraph 117 of IAS1?

6. Which company verifies the financial statements of the entity?

7. Does the entity disclose both indexes of EPS (earnings per share) in the Profit and Loss Statement and Other Comprehensive Income in accordance with IAS 33 ?

8. How many pages are there in Notes section? 